\title{
Alternative Investment Fund Managers Directive and its Impact on Malta's Financial Service Industry
}

\author{
Simon Grima ${ }^{1}$, Inna Romānova ${ }^{2}$, Frank Bezzina ${ }^{3}$, Frank Chetcuti Dimech ${ }^{4}$
}

\begin{abstract}
:
The introduction of the Directive on Alternative Investment Fund Managers (AIFM Directive 2011/61/EU) in 2013 means a radical transformation of the EU regulatory landscape for the whole alternative investment fund industry. Taking into account the growing meaning of the alternative investment fund industry in Europe, the aim of the paper is to assess the impact the Directive on Alternative Investment Fund Managers (AIFMD) will have on the Alternative Investment Fund Managers (AIFMs) managing Alternative Investment Funds (AIFs) in the EU.

The research is based on the case of Malta, which is a quickly growing financial centre. The main findings are based on an analysis of questionnaire responses conducted with key players in the fund industry regulated and licensed by the Malta Financial Services Authority. This study provides an extensive analysis of the AIFMD and its impact on Malta's financial service industry. It has highlighted various factors that will have a positive or negative impact on the industry resulting from the AIFMD.
\end{abstract}

The paper provides recommendations for further development of the Maltese fund industry in the context of the AIFMD that can be partially applied to other fund domiciles.

Key Words: Alternative Investment Fund Managers Directive (AIFMD), investment fund managers, incentives, disincentives, Malta.

JEL Codes: C23, C24

${ }^{1}$ University of Malta, Malta;

${ }^{2}$ University of Latvia, Latvia, Corresponding author-e-mail address

(inna.romanova@lu.lv), phone number+37167034632.

${ }^{3}$ University of Malta, Malta;

${ }^{4}$ University of Malta, Malta; 


\section{Introduction}

In June 2011, the European Commission proposed a new Directive (AIFM Directive 2011/61/EU) on Alternative Investment Fund Managers (AIFM). The aim of this Directive is to establish common requirements governing the authorization and supervision of AIFMs in order to provide a coherent approach to the related risks and their impact on investors and markets in the European Union (Directive, 2011).

According to the requirements, the AIFM directive should be in place across the whole of the European Union by the end of July 2014, thus establishing an EU-wide harmonized framework for monitoring and supervising risks as well as imposing more rigorous regulation on alternative investment fund managers. The AIFM Directive covers different types of alternative investment funds, e.g., hedge funds, private equity funds, real estate funds, retail investment funds, as well as alternative investment companies. Thus, this Directive means a radical transformation of the EU regulatory landscape for the whole alternative investment fund industry.

The reaction of the investment fund industry was rather equivocal. On one hand, the Directive creates a European passport system for alternative investment fund managers (AIFMs), thus allowing distribution of these investment funds to professional investors. On the other hand, new regulations bring additional work for alternative managers to get the processes and procedures in place, especially concerning regulatory reporting, depositary requirements, risk management and certain disclosures to investors. Besides, some rules are still unclear, like remuneration rules of alternative managers.

The AIFM Directive requires enhanced transparency of alternative managers (European Commission, 2012) and the investment funds they manage, thus offering investors an additional protection and giving more clarity in such important issues like taxation of carried interest. On the other hand, assurance of additional transparency means extra costs for the alternative fund managers that in most cases will be transposed to investors.

Therefore, the new Directive with the imposition of a licensing and regulatory compliance framework on the managers of alternative investment funds (AIFs) which are marketed or managed in the EU, will have significant implications for financial sponsors across the globe, let alone small domiciles such as Malta. The Directive introduced some transitional periods, as follows:

- One year transitional period until 22 July, 2014 for existing fund managers / self-managed funds to upgrade their licenses into full AIFMs / self-managed AIFs or de minimize AIFMs.

- Non-EU fund managers may continue to manage / market without a passport non-EU AIFs / EU AIFs without requiring full AIFMD compliance until 2015. 
- AIFMs and AIFs are allowed to engage both local depositaries as well as a depositary that is a credit institution in another EU Member State until 22 July, 2017.

The transposition of the AIFM directive into national legislation might create additional advantages to some market players, as the Directive provides some discretion for Member States. For example, it allows private placement of non-EU alternative investment funds (AIFs) marketed by EU-based alternative investment fund managers (AIFMs) and AIFs marketed by non-EU AIFMs. Furthermore EU AIFs, especially of the self-managed type, may still benefit from national private placement regimes. Thus the final requirements may vary significantly among the EU Member States.

Therefore the aim of the paper is to assess the impact AIFMD will have on AIFMs managing AIFs in Malta. After over-viewing key concepts associated with the AIFMD and possible impacts of this directive on the AIF industry, this paper focuses exclusively on the Maltese fund industry. It investigates various factors that might have a positive or negative impact on the industry resulting from the AIFMD. Malta is a small island state situated in the centre of the Mediterranean Sea with a population of circa 400,000 persons. It is a member of the EU and forms part of the Eurozone. Malta's key economic figures for 2015, when compared to the 17 countries that have adopted the euro, are shown in the Table 1 below:

Table 1. Malta's Economic Figures

\begin{tabular}{|l|l|l|}
\hline & Malta & Euro Area 17 \\
\hline GDP per capita & EUR 16'100 & EUR 28'500 \\
\hline Economic growth & $1 \%$ & $-0.6 \%$ \\
\hline Debt-to-GDP & $72.1 \%$ & $90.6 \%$ \\
\hline Inflation & $3.2 \%$ & $2.5 \%$ \\
\hline Unemployment rate & $6.4 \%$ & $11.4 \%$ \\
\hline
\end{tabular}

Source: Eurostat data

Economic growth and stability are highly dependent on financial services (Falzon, 2011) and so the issues raised in this paper are very important for Malta's growth as well as for other member states that will be influenced by this Directive. The findings will be discussed and the study goes to provide recommendations aimed at better guiding Maltese authorities to adapt to the changes brought forth by the AIFMD and to ensure that the Maltese Fund Industry can continue to grow and prosper. Various prominent researchers have used islands as case studies for policy and development studies (King, 1993). Hence, the recommendations of this study can be also partially applied to other investment fund domiciles. 


\section{Theoretical Framework and Literature Review}

The investment fund industry can be seen as one of the key drivers of financial market and the economy as a whole. Several studies point out that investment funds facilitate innovations in other sectors of economy (Njegomir \& Demko Rihter, 2013; Thalassinos et al., 2015), support economic growth and improve social welfare (Chou \& Chin, 2004). Investment funds accumulate capital, ensure risk diversification and provide investors new investment diversification options, realizing financial innovations through new assets classes, new asset allocation techniques, new risk and returns enhancing tools, new theme funds and new business models (Rajan, 2011). Moreover, the alternative investment industry covering hedge funds, private equity funds, real estate funds etc. is often seen a benefit for the financial market it operates in, enhancing market liquidity and efficiency (e.g., hedge funds) as well as expanding sources of available corporate financing (e.g., private equity funds) (Ferran, 2011; Rupeika-Apoga and Nedovis, 2015; Fetai, 2015). Thus the introduction of the Directive on Alternative Investment Fund Managers will have an impact not only on the particular funds, but also on financial markets and economies as a whole.

The idea of pan-European regulation of investment funds is not new. In 1985 the UCITS (Undertakings for Collective Investment in Transferable Securities) Directive was invented introducing European harmonized investment funds (Directive 85/611/ECC, 1985). The aim of the UCITS Directive was to allow collective investment schemes to operate freely throughout the European Union on the basis of a single authorization from one member state. Later the directive had to be applied in all EEA countries, thus including also Iceland, Norway and Liechtenstein. This harmonized legal framework had a strong focus on investors' protection and product regulation.

Changing economic environment as well as market pressure gave an incentive to ensure further improvement of the investment fund regulatory framework. In 2001 UCITS III Directives (Directive 2001/107/EC "Management Directive" \& Directive 2001/108/EC "Product Directive") were introduced enabling wider range of eligible assets, extended use of derivatives as well as improved regulation of investment fund management companies (Directive 2001/107/EC, 2001; Directive 2001/108/EC, 2001). Currently the UCITS IV Directive is in place, enabling a simplified notification process and key investor information document, regulating cross-border merger, providing the possibility to obtain a management company passport, and to establish master-feeder structure on a local and cross-border basis etc (Directive 2009/65/EC, 2009).

Still, the establishment of the pan-European regulatory framework for investment funds is an ongoing process. UCITS V proposals are already published (in July 2012) enhancing regulation of depository regime (including duties, delegation, eligibility and liability), rules governing remuneration as well as a sanctions regime. 
The second step in the establishment of a pan-European regulation of the investment fund industry is the introduction of the new Directive on Alternative Investment Fund Managers (AIFM Directive 2011/61/EU) to establish common requirements governing the authorization and supervision of alternative investment fund managers and funds.

The consultation paper on key concepts of the Alternative Investment Fund Managers Directive and types of AIFM published in February 2012 was widely discussed (ESMA, 2012) by numerous investment fund industry participants and financial experts (Alternative Investment Management Association, Association Française de la Gestion financière, Association of Foreign Investment Companies in Austria, BVI Bundesverband Investment and Asset Management, EFAMA, Investment Management Association, German Banking Industry Committee, ALFI, PricewaterhouseCoopers and many others).

The introduction of the AIFM Directive in 2013 was taken by the investment fund industry rather equivocal. The scope of the Directive is rather broad, including management and marketing of AIFs, requirements of AIF managers authorization, EU marketing passport, private placement exemptions to professional investors, capital requirements, remuneration, risk management, reporting and repository requirements. Besides, different rules should be applied depending on whether the alternative investment fund and fund manager are based in the EEA or outside EEA.

The impact of the Directive on the investment fund industry is still unclear. Several studies conducted by industry professionals have shown that most market participants see the AIFM Directive as a threat to their business and competitiveness of the industry in Europe (Deloitte, 2012). Besides, the Directive may put some alternative investment fund markets in a weak competitive position as an alternative fund and management company domicile. The European asset management industry employs ca.510, 000 specialists across European countries and has an annual Gross value added of 102.6 billion EUR (European Fund and Asset Management Association, 2013). Change of competitiveness of domiciles may put it under risk.

According to a survey of UK based asset managers carried out by Deloitte, nearly three quarters of respondents see the Directive as a threat to their business and two thirds believe that AIFM Directive will reduce competitiveness of the alternative investment fund industry in Europe (Deloitte, 2012). Therefore, it is extremely important to assess the impact of AFMD on the industry as a whole and on the competitiveness of the domiciles affected by it.

The fact that, after the end of the transitional period in 2017, the depositary must be located in the AIF's domicile could also cause concerns in smaller financial centres. Furthermore, the rules on depositary liability and responsibilities could lead to increasing costs for AIFs and reduction of competition since certain market participants could leave the custody market. Thus, the assessment of the possible 
impact of the AIFM directive is important to provide recommendations to maintain/improve competitiveness AIF domiciles.

\section{Research Methodology and Results}

The paper investigates the following three research questions empirically:

1. Following the AIFMD, how important will specific incentives be for retaining/obtaining an AIF license in Malta?

2. Following the AIFMD, how important will specific disincentives be for retaining/obtaining an AIF license in Malta?

3. Does the intention to retain/obtain an AIF license in Malta following the AIFMD vary as a function of the size of the Fund, whether the Fund Manager is already licensed in Malta and whether the Fund Manager has a licensed Fund in Malta?

To answer these questions, we targeted all players in the fund industry comprising 71 Fund Managers and 231 licensed Funds regulated and licensed by the Malta Financial Services Authority [MFSA]. Additionally, we targeted potential AIF license holders; i.e., those who intend to obtain an AIF license in Malta in the next two years (population not available). With no sampling frame available for the latter, we resorted to 'critical-case purposive sampling' (Saunders, Thornhill, \& Lewis, 2009). Our distribution strategy focused on two fronts - our personal network involved in the AIF industry who voluntarily agreed to help us in getting exposure, and Linkedin related groups/ forums in which one of the authors has been a member for a long time. All the data were gathered via a web-link on kwiksurveys.com and no incentives were offered to the participants for answering the questionnaire.

\section{The Research Instrument}

The questionnaire entitled 'Alternative Fund Managers' Directive and its Implications for Malta’ consisted of:

- 5 closed ended demographic variables regarding the Fund Manager's Fund and license (e.g., 'Is the Fund Manager Licensed in Malta?').

- 22 randomly ordered, five point Likert-style questions ranging from 'strongly disagree' to 'strongly agree' comprising 11 incentives for retaining/obtaining an AIF license in Malta following the AIFMD (e.g., 'Lower running costs in Malta [e.g., legal/administration/authorization fees] when compared with other established jurisdictions') and 11 disincentives for retaining/obtaining an AIF license in Malta following the AIFMD (e.g., 'Lack of internationally established custodians/depositaries'). Some of these statements were adapted from various sources that we consulted during the literature search, e.g., MFSA publications (MFSA, 2013), Kinetic Partners (Kinetic Partners, 
2013), Deloitte (Deloitte, 2012), Ernst \& Young (Ernst \& Young, 2013) while others were designed by the authors following discussion with experts in the field.

- another 3 five-point Likert type items regarding the Fund or Fund Manager's intention to retain/obtain a license in Malta following the AIFMD (e.g., 'The AIFMD will not affect the Fund/Fund Manager decision to retain/obtain the AIF license in Malta'), the latter being restricted to those Fund Managers who had a licensed fund or a Fund Manager license in Malta.

The respondents were able to amend their responses until the questionnaire was completed, while the software allowed one respondent per IP address, thereby helping prevent multiple completions from the same respondent or from the same Fund Manager. We stressed that there were no 'right' or 'wrong' answers to the statements, that confidentiality and anonymity were guaranteed, and that the individual responses would be used for research purposes to help see the 'big picture'. The questionnaire took approximately 10 minutes to complete.

\section{Data Analysis Procedures}

To answer the first two research questions, we started by generating descriptive statistics for each of the 11 incentives and 11 disincentives using the median (Md), the range (R), the mean (M), the standard deviation (SD) and mean rank (MR). To test for difference in mean ranks across the various ordinal scales, we conducted the Friedman test. In the presence of a significant $\chi^{2}$ statistic in the Friedman test, we computed a series of Wilcoxon tests as post-hoc tests, applying the Bonferroni correction to avoid the problem of inflating the Type 1 error due to multiple comparisons (Miller, 1991).

To answer the third research question, we used stepwise multiple regression. 'Intention to retain/obtain the License in Malta following AIFMD' was included as the dependent variable, while 'size of Fund', whether or not 'the Fund manager is already licensed in Malta' and whether or not 'the Fund manager has a licensed fund in Malta' were included as independent variables. Before interpreting the results, we ensured that the assumptions of no autocorrelation in the residuals and multicollinearity were not violated by means of the Durbin-Watson statistic and the VIFs respectively.

\section{Sample Characteristics}

A total of 299 persons responded to our invitation during the February 2014. From these, the responses of 29 participants were discarded because one of the following three requirements was not met: (1) Fund Manager was already licensed in Malta, (2) the Fund was licensed in Malta, and (3) the Fund or Fund Manager had the intention to obtain a new license in Malta within the next two years. Thus, 270 
complete surveys formed the basis of the statistical analysis. Of these, $38(14.1 \%)$ have a Fund Manager license in Malta, 112 (41.5\%) have a licensed fund in Malta, and the remaining $120(44.4 \%)$ represented prospective AIF license holders. 173 $(64.1 \%)$ respondents have the Fund Manager licensed in the EU. Also, 137 (50.7\%) reported that the size of the Fund (Assets under Management) was below 100 million euro with the remaining $133(49.3 \%)$ reporting that the size of the Fund was between 100 million and 250 million euro. No Fund in the sample exceeded 250 million euro in Assets under Management including leverage.

Table 2 exhibits the population and sample distributions by license type. The sample size of 150 for Fund managers of Funds licensed in Malta (which excluded the 120 prospective AIF license holders) already exceeded the a-priori minimum sample size of 30 for the Friedman test and associated Wilcoxon post-hoc tests (Green \& Salkind, 2008). It also exceeded the minimum a-priori sample size of 112 for multiple regression for the following pre-set criteria - three predictors, desired statistical power of 0.8 , Type 1 error rate of 0.05 , and an anticipated effect size of 0.10 (Soper, 2014).

A Chi-squared test of independence revealed that the population and sample distributions by license type did not differ significantly from each other $\left(\chi^{2}(1)=\right.$ $0.008, \mathrm{p}=0$. 930). This confirmed the representativeness of our sample, thereby increasing our confidence in making generalizations for the sample to the population in question. Since MFSA was not in a position to provide us a list of prospective AIF licence holders due to Data Protection, they had to be excluded from the Chisquared analysis of independence.

Table 2. Population and sample distributions by license type

\begin{tabular}{lcc}
\multicolumn{1}{c}{ Licence Type } & Population & Sample \\
Have a Fund Manager licence in Malta & $73(25.5 \%)$ & $38(25.3 \%)$ \\
Have Licenced Fund(s) in Malta & $213(74.5 \%)$ & $112(74.7 \%)$ \\
Total & $286(100.0 \%)$ & $150(100.0 \%)$
\end{tabular}

Source: Authors' calculations based on the survey made.

\section{Following the AIFMD, how important will specific incentives be for retaining/obtaining an AIF license in Malta?}

The Friedman test revealed that that the incentives $(\mathrm{N}=11)$ differed significantly with respect to their mean $\operatorname{ranks}\left(\chi^{2}(10)=1725.30, \mathrm{~N}=238, \mathrm{p}<0.001\right)$. In fact, the most important incentive $(\mathrm{Md}=5)$ that emerged was that the running costs in Malta would be lower than in other established jurisdictions. Other important incentives $(\mathrm{Md}=4)$ that emerged were 'tax incentives', 'Malta as a member of the EU (including EU passport)', 'the Financial Services infrastructure and robust Financial Services Regulator', and 'the economic climate in Malta'. A summary of descriptive statistics and post-hoc analysis with Wilcoxon Signed Ranks tests is presented in Table 3 below. 
Table 3. Descriptive Statistics and Wilcoxon Signed Ranks Test Summary (Incentives)

\begin{tabular}{|c|c|c|c|c|c|}
\hline $\begin{array}{c}\text { Incentives for obtaining/retaining an } \\
\text { AIF Licence } \\
\text { following AIFMD } \\
\end{array}$ & MR & MD (R) & $\mathbf{M}$ & SD & WPHT* \\
\hline $\begin{array}{l}\text { Lower running costs in Malta when } \\
\text { compared to other established jurisdictions }\end{array}$ & 9.47 & $5(2-5)$ & 4.55 & 1.05 & A \\
\hline Tax incentives & 9.07 & $4(3-5)$ & 4.17 & 0.44 & B \\
\hline $\begin{array}{l}\text { Malta being a member of the EU } \\
\text { (including EU passport) }\end{array}$ & 8.72 & $4(3-5)$ & 4.03 & 0.28 & $\mathrm{C}$ \\
\hline $\begin{array}{c}\text { The Financial Services infrastructure and } \\
\text { robust Regulator }\end{array}$ & 7.84 & $4(3-4)$ & 3.84 & 0.37 & $\mathrm{D}$ \\
\hline The economic climate in Malta & 7.20 & $4(3-4)$ & 3.70 & 0.46 & $\mathrm{E}$ \\
\hline The legal system in Malta & 5.27 & $3(3-4)$ & 3.20 & 0.40 & $\mathrm{~F}$ \\
\hline The political climate in Malta & 4.62 & $3(3-4)$ & 3.05 & 0.23 & G \\
\hline Availability of multi-lingual personnel & 4.62 & $3(3-4)$ & 3.05 & 0.23 & G \\
\hline $\begin{array}{l}\text { Maltese culture and history (UK traditional } \\
\text { banking culture) }\end{array}$ & 4.41 & $3(3-3)$ & 3.00 & 0.00 & $\mathrm{H}$ \\
\hline The technological infrastructure & 2.70 & $2(2-4)$ & 2.41 & 0.59 & I \\
\hline The productivity of the labour force & 2.09 & $2(2-4)$ & 2.28 & 0.56 & $\mathrm{~J}$ \\
\hline
\end{tabular}

WPHT = Wilcoxon post-hoc tests; $*$ different letters signify statistically significant differences between groups $(p<0.001)$ following Bonferroni correction

Source: Authors' calculations based on the survey made.

\section{Following the AIFMD, how important will specific disincentives be for retaining/obtaining an AIF license in Malta?}

The Friedman test revealed that that the disincentives $(\mathrm{N}=11)$ also differed significantly with respect to their mean ranks $\left(\chi^{2}(10)=1082.384, \mathrm{~N}=238, \mathrm{p}<\right.$ $0.001)$. In fact, the most important disincentives $(\mathrm{Md}=4)$ were 'insufficient number of custodians/depositaries', 'lack of internationally established custodians/depositaries' and 'the marketing of AIFs to non-professional investors'. A summary of descriptive statistics and post-hoc analysis with Wilcoxon Signed Ranks tests is presented in Table 4 below.

Table 4. Descriptive Statistics and Wilcoxon Signed Ranks Test Summary (Disincentives)

$\begin{array}{cccccc}\begin{array}{c}\text { Disincentives for obtaining/retaining an } \\ \text { AIF Licence }\end{array} & \text { MR } & \text { MD (R) } & \text { M } & \text { SD } & \text { WPHT* } \\ \begin{array}{c}\text { following AIFMD } \\ \begin{array}{c}\text { Insufficient number of } \\ \text { custodians/depositaries }\end{array}\end{array} & 9.04 & 4(3-4) & 3.97 & 0.16 & \text { A } \\ \begin{array}{c}\text { Lack of internationally established } \\ \text { custodians/depositaries }\end{array} & 8.85 & 4(3-4) & 3.92 & 0.27 & \text { A,B } \\ \begin{array}{c}\text { The marketing of AIFs to non-professional } \\ \text { The }\end{array} & 8.41 & 4(2-5) & 3.87 & 0.71 & \text { B }\end{array}$
investors 


\begin{tabular}{|c|c|c|c|c|c|}
\hline $\begin{array}{l}\text { Fund manager needs to comply with } \\
\text { AIFMD even if fund is } \\
\text { smaller than } € 100 \text { million }\end{array}$ & 5.82 & $3(3-5)$ & 3.42 & 0.73 & $\mathrm{C}$ \\
\hline $\begin{array}{l}\text { No passporting possibilities currently } \\
\text { available for depositories /custodians }\end{array}$ & 5.14 & $3(3-5)$ & 3.29 & 0.70 & $\mathrm{D}$ \\
\hline $\begin{array}{l}\text { Increased custody costs due to additional } \\
\text { responsibilities of } \\
\text { custodian (depositary) }\end{array}$ & 5.02 & $3(2-5)$ & 3.00 & 0.71 & $\mathrm{D}, \mathrm{E}$ \\
\hline $\begin{array}{c}\text { Insufficient availability of qualified risk } \\
\text { managers in Malta }\end{array}$ & 4.89 & $3(3-4)$ & 3.13 & 0.34 & $\mathrm{E}$ \\
\hline $\begin{array}{c}\text { Requirement of professional indemnity } \\
\text { insurance and } \\
\text { associated costs }\end{array}$ & 4.89 & $3(3-4)$ & 3.13 & 0.34 & E \\
\hline $\begin{array}{l}\text { Possible negative impact of tax } \\
\text { harmonisation within EU member states on } \\
\text { Malta's current favourable tax regime }\end{array}$ & 4.87 & $3(2-5)$ & 3.23 & 0.76 & E \\
\hline $\begin{array}{l}\text { The harmonisation of the definition of } \\
\text { professional investor under AIFMD }\end{array}$ & 4.87 & $3(2-5)$ & 3.23 & 0.76 & E \\
\hline $\begin{array}{l}\text { Malta's immature (embryonic) Fund } \\
\text { Industry when compared to traditional } \\
\text { centres }\end{array}$ & 4.21 & $3(3-3)$ & 3.00 & 0.00 & $\mathrm{~F}$ \\
\hline
\end{tabular}

Source: Authors' calculations based on the survey made.

Does the intention to retain/obtain an AIF licence in Malta following the AIFMD vary as a function of the size of the Fund, whether the Fund Manager is already licensed in Malta and whether the Fund Manager has a licensed Fund in Malta?

In the survey, we asked those who currently have a licensed Fund and/or a Fund Manager license in Malta to rate their level of agreement with three five-point Likert-type items concerning their intention to retain/obtain a license in Malta following the AIFMD. Since the measures pertaining to these three items were internally consistent (Cronbach $\alpha=0.845$ ) and loaded on a single factor in Principal Component Analysis (Eigen-value $(\lambda)=2.09, \%$ of variance $=69.53$ ) we summed the scores of each participant together and found the average score, to obtain the 'Intention' scale (dependant variable in stepwise multiple regression analysis).

Stepwise multiple regression analysis revealed that the intention to retain/obtain a License in Malta following the AIFMD was significantly predicted by possession (No/Yes) of a licensed fund in Malta. In fact, those Fund Managers who currently have a licensed Fund in Malta $(\beta=0.316, \mathrm{t}=3.59, \mathrm{p}<0.001)$ have a greater intention to retain a License in Malta following the AIFMD. 'Size of Fund' ( $\beta=$ $0.131, \mathrm{t}=1.38, \mathrm{p}=0.17$ ) and possession of a Fund Manager licence (No/Yes) in Malta' $(\beta=0.015, \mathrm{t}=0.16, \mathrm{p}=0.88)$ did not have a significant impact on 'intention' 
and so these variables were excluded from the model. Table 5 below provides a summary of the stepwise multiple regression output.

Table 5. Stepwise Multiple Regression Coefficients Table

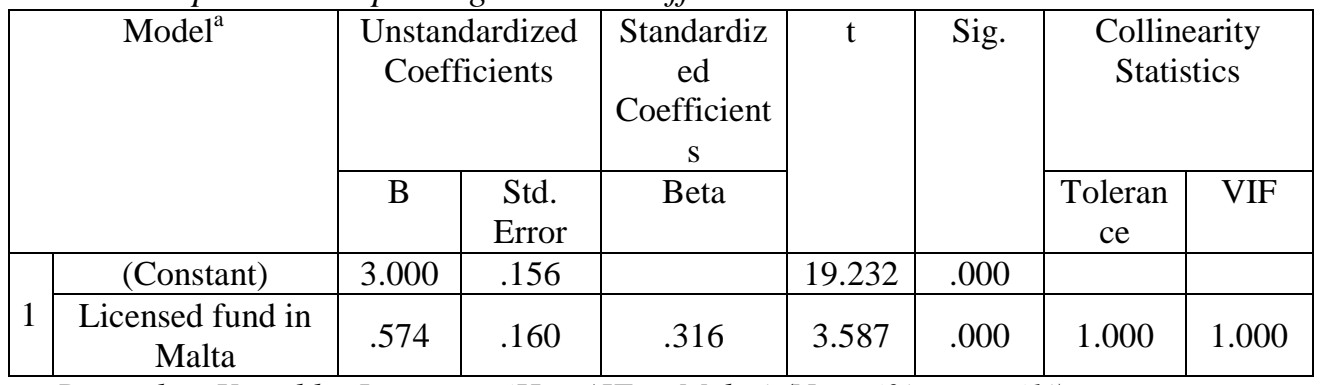

a. Dependent Variable: Intention; 'Has AIF in Malta' (No = '0', yes = '1')

Source: Authors' calculations based on the survey made.

With respect to the statistical assumptions of regression analysis, it is worth noting that with one regressor, multicollinearity is not an issue (Field, 2009). With one regressor, an intercept in the model and a sample size of 118 , the observed DurbinWatson statistic $(d=2.24)$ was greater than 2 . Hence, we tested the null hypothesis of no autocorrelation in the residuals versus negative first-order autocorrelation at the $5 \%$ level of significance. We computed $4-d(=1.76)$ and compared the result with the tabulated $5 \%$ significance points of $\mathrm{dL}=1.654$ and $\mathrm{dU}=1.694$ (Savin \& White, 1977). Since 1.76 is higher than 1.694 , we retained the null hypothesis of no autocorrelation.

\section{Discussion}

The first goal of this study was to determine the importance of specific incentives for Fund Managers and Funds in obtaining/retaining an AIF License in Malta following the AIFMD. The most important incentive that emerged was that the running costs in Malta will still remain lower than in other established jurisdictions. This gives Malta the advantage of cost competitiveness and its effect is expected to be most pronounced with start-up fund managers, although more established fund managers looking to relocate to Malta would also be expected to consider this advantage positively.

Malta is known to provide high quality and efficient services and hence one can gain global brand service provisions from tier two service providers at very competitive prices without losing on quality. Such costs include renting, legal fees, telecommunication and IT services costs, Audit fees and a well-trained and productive staff complement. The second most important incentive for obtaining/retaining an AIF licence following the AIFMD was related to tax incentives. 
Although the taxation of funds itself is zero or near zero in the most important European fund domiciles, and the VAT exemption for investment management is settled EU case-law, Malta's advantage lies in its full imputation system of taxation which avoids double taxation of corporate profits. In addition, a number of tax treaties further enhance Malta's offering. Tax incentives help to reduce discrimination with countries that are already attractive, and this makes sense in the context of a small island state like Malta (Bezzina, Falzon \& Zammit, 2012, p. 595).

In fact, Maltese authorities continuously conduct a rethinking of tax incentives to ensure that they at least match those offered by other competing domiciles. The third most important incentive selected was that Malta is a member of the EU. This provides Fund Managers and Funds the opportunity for EU pass-porting, enhances transparency and standardization, and reduces the possibility of regulatory arbitrage among jurisdictions. The fourth important incentive concerned the financial services regulator (MFSA) in Malta, which is slowly but steadily developing into one of the most robust yet business-oriented regulators in the EU. The fifth important incentive related to the economic climate in Malta. The way in which the Maltese economy went unscathed through the recent global financial crisis provides clear evidence of the resilience of the Maltese economy.

In fact, Malta did not have to resort to any bank bailouts and its banking system has been ranked as the 13th most solvent out of 144 countries (World Economic Forum, 2013). Additionally, a recent study by Bezzina, Grima and Mamo (2014, in press) shows that Maltese financial firms have sound risk management practices that link positively with added value and principled performance.

The second goal of this study was to determine the importance of specific disincentives for Fund Managers and Funds in obtaining/retaining an AIF Licence in Malta following the AIFMD. The two most important disincentives that were ranked on par concerned AIFMD requirements - the 'insufficient number of custodians/depositaries', and the 'lack of internationally established custodians/depositaries'. It is clear that Malta needs a quick solution to its depositary offering. Malta needs to attract depositaries that are open for the wide array of alternative investments and fund sizes. The problem here is that although Malta has a few big names, they have been reluctant to act as custodians of a certain size or type of investment.

A possible solution to this problem would be to encourage the European Commission to push relentlessly forward its plans for a pan-European passport for the depositary, thus allowing depositaries to provide cross-border services. This is a missing link in the European integration of financial markets.

However, Maltese authorities do not seem to be in favor of this proposal, arguing that it is not exactly in line with the spirit of the requirements. The other factor that emerged as an important disincentive was 'the marketing of AIFs to non- 
professional investors'. The results of the questionnaire show that AIFMD is generating interest from medium to smaller managers who are attracted to the possibility of a European passport to market their fund to professional investors across the EU. However the authors consider that the current legislation is too polarized between professional investors and retail investors. There exists another category of investor that is wealthy enough not to be considered as retail, yet would not meet the strict criteria of a professional investor. Within that space, marketing will still be dominated by national rules which were left unharmonized by AIFMD. Here Malta's role will be to reach out to other European regulators and gain an even better understanding of national private placement rules in order to be able to offer solutions for the benefit of Fund Managers and Funds in Malta.

An unexpected finding in relation to disincentives following the AIFMD was that the limited number of risk managers on the Island did not emerge as a preoccupation for the respondents. Possible explanations could be that most of the Fund Managers and Funds already have a strong setup for this function and so the lack of risk managers on the island will not impact negatively on their decision.

In this regard, the MFSA's training arm, the Malta International Training Centre (MITC), the Malta Association of Risk Management (MARM), the University of Malta and other private institutions have been providing training courses and seminars over the last three years to fill this gap. Additionally, MFSA is currently exploring additional/alternative initiatives in this regard to boost the number of qualified risk managers on the Island.

The third and final goal of this study was to determine whether the intention to obtain/retain a Fund Manager license and/or a Fund license in Malta following the AIFMD varied as a function of the size of the Fund, possession of a Fund Manager license in Malta, or possession a Fund license in Malta. The analysis revealed that those who have a fund licensed in Malta are more likely to obtain/retain their licence after the AIFMD than others who do not have a fund. Further scrutiny of the data revealed that this was due to Fund Managers licensed in Malta who still do not have any funds under management, and this might have negatively impacted their outlook. This finding however warrants further investigation before any strong conclusions may be drawn.

\section{Conclusions}

This study provides a comprehensive picture of the importance of specific incentives and disincentives for Fund Managers and Funds in obtaining or retaining an AIF license in Malta following the AIFMD. Firstly, four specific incentives emerged as important in attracting Fund Managers and Funds to obtain/retain an AIF license in Malta following the AIFMD; namely, lower running costs, tax incentives, the stable economic climate, and EU pass porting. Secondly, three specific disincentives in obtaining/retaining an AIF License following the AIFMD are identified: namely, an 
insufficient number of custodians/depositaries, a lack of internationally established custodians/depositaries and the marketing of AIFs to non-professional investors. Thirdly, the study shows those who already have a licensed fund in Malta had a greater intention to obtain/retain an AIF license following the AIFMD, with the size of fund and possession of a Fund manager license not producing any impact on intention.

In the light of the findings, various proposals have need highlighted. Of particular importance are (i) the need to attract custodians that are open for the wide array of alternative investments and fund sizes, and (ii) that private placement rules include another category of investors that is in between the profession and the retail investor. Such proposals could better guide Maltese authorities to reduce the impact of the AIFMD on the Maltese fund industry and to help it develop successfully in the coming years. The conclusions and recommendations of this study can be also partially applied to other investment fund domiciles.

There are some limitations to the findings, however, that should be noted. First, the data used in this study were gathered from a single jurisdiction (Malta) and so it was not possible to make cross-jurisdiction comparisons. Second, the findings are based on a survey and we are not in a position to verify that a non-questionnaire approach would have generated similar findings. Third, the dis/incentives specified in this study for obtaining/retaining an AIF license may not be exhaustive and there may be other important factors that could be investigated in future studies.

Despite these limitations, some interesting avenues for further research emerge. For instance, it would be interesting to conduct this study in other jurisdictions to facilitate cross-jurisdiction comparisons. Additionally, further research is required to determine the types of initiatives required to attract the establishment of depositories in Malta that accept custody of smaller funds with different underlying investments or profiles, and to find ways of increasing the redomiciliation of non EU funds to the EU.

To remain attractive, Malta needs to make sure that the reasons that attracted Fund Managers and Funds to Malta are be kept in place and possibly improved when these managers take the step up to comply with AIFMD. The Maltese requirements for fund managers are already largely compliant with AIFMD. The MFSA and other institutions and Associations such as MARM and Finance Malta must keep working in tandem to devote all possible resources to help Fund Managers to make it through the transition period so that the AIFMD would have an overall positive impact on Malta's fund industry.

\section{References}

Athanassiou P. (2010). The Draft AIFM Directive and The Future of European Alternative Investment Fund Regulation. CESifo DICE Report 1/2010, vol. 8, issue 1. 
Beythan H. \& Virard-Canto C. (2012). Is the Draft UCITS V Directive a Cloned Version of the Alternative Investment Fund Managers Directive? Journal of Securities Operations \& Custody, vol. 5, Number 1, pp.64-72.

Bezzina, F., Falzon, J. \& Zammit, M. (2004). Manufacturing in Malta: Opportunities, Challenges and Policy Implications, in D. Tipuric \& M. Dabic (Eds.) Management, Governance, and Entrepreneurship - New Perspectives and Challenges. Darwen, UK: Access Press, pp. 588-605.

Bezzina, F., Grima, S. \& Mamo, J. (2014). Risk Management Practices Adopted by Financial Firms in Malta. Managerial Finance, in press.

Black D. (2009). The draft EU Directive on Alternative Investment Fund Managers: What's the Fuss about? Journal of Securities Law, Regulation \& Compliance, vol. 3, Number 1, pp.64-70.

Chou, Y. \& Chin, M.S. (2004). Financial Innovations and Technological Innovations as Twin Engines of Economic Growth. Mimeo University of Melbourne.

Council Directive 2011/61/EU. (2011). Directive on Alternative Investment Fund Managers and Amending Directives 2003/41/EC and 2009/65/EC and Regulations (EC) No $1060 / 2009$ and (EU) No 1095/2010

Council Directive 2009/65/EC. (2009). Directive of 13 July 2009 on the Coordination of Laws, Regulations and Administrative Provisions Relating to Undertakings for Collective Investment in Transferable Securities (UCITS).

Council Directive 2001/107/EC. (2001). Directive of 21 January 2002 Amending Council Directive 85/611/EEC on the Coordination of Laws, Regulations and Administrative Provisions Relating to Undertakings for Collective Investment in Transferable Securities (UCITS) with a View to Regulating Management Companies and Simplified Prospectuses.

Council Directive 2001/108/EC. (2001). Directive of 21 January 2002 amending Council Directive 85/611/EEC on the Coordination of Laws, Regulations and Administrative Provisions Relating to Undertakings for Collective Investment in Transferable Securities (UCITS), with Regard to Investments of UCITS.

Council Directive 85/611/ECC. (1985). Directive of 20 December 1985 on the Coordination of Laws, Regulations and Administrative Provisions Relating to Undertakings for Collective Investment in Transferable Securities (UCITS)

Deloitte. (2012). Responding to the New Reality Alternative Investment Fund Managers Directive Survey. [Online] Available at: http://www.deloitte.com/assets/DcomUnitedKingdom/Local\%20Assets/Documents/Industries/Financial\%20Services/ukfs-aifmd-survey-responding-new-reality.pdf [Accessed 10 January 2014].

Ernst \& Young. (2013). The Alternative Investment Fund Managers Directive.

ESMA. (2014). Key Concepts of the Alternative Investment Fund Managers Directive and Types of AIFM. [Online] Available at:

http://www.esma.europa.eu/consultation/Key-concepts-Alternative-Investment-

Fund-Managers-Directive-and-types-AIFM [Accessed 2 February 2014].

European Commission. (2012). Executive Summary of the Impact Assessment. [Online] Available at http://ec.europa.eu/internal_market/investment/docs/20121219directive/ia-resume_en.pdf [Accessed 10 January 2014].

European Fund and Asset Management Association. (2013). Asset Management in Europe Facts and Figures. [Online] Available at: http://www.efama.org/Publications/Statistics/Asset\%20Management\%20Report/Ass et_Management_Report_2013.pdf [Accessed 6 January 2014].

Falzon, J. (2011). An Analysis of the Productive Sectors of the Maltese Economy: a 
Comparison with EU Member States. [Online] Available at:

http://www.maltamanagement.com/wp-content/uploads/2011/04/prof-falzon.pdf

[Accessed 6 January 2014].

Ferran, E. (2011). After the Crisis: The Regulation of Hedge Funds and Private Equity in the

EU. European Business Organization Law Review, vol.12, Issue 03, pp. 379 - 414.

Field, A. (2009). Discovering Statistics Using SPSS. London, Sage.

Fetai, B. (2015). Financial Integration and Financial Development: Does Financial Integration Matter? European Research Studies Journal, 18(2), 97-106.

Green, S.B. \& Salkind, N.J. (2008). Using SPSS for windows and Macintosh: Analysing and understanding data. Upper Saddle River, NJ: Pearson / Prentice Hall.

Jud T. \& Marchart J. (2013). Mögliche Konsequenzen der Umsetzung der EU-Richtlinie zum Management alternativer Investmentfonds für die Österreichische

Risikokapitalbranche, WIFO-Monatsberichte 8/2013, S.699-706.

Kinetic Partners. (2013). AIFMD Risk Solution.

King, R. (1993). The geographical fascination of islands, in D.G. Lockhart, D. DrakakisSmith. \& J. Schembri, J. (Eds.) The Development Process in Small Island States, Routledge, London, pp. 13-37.

Linklaters. (2013). AIFM Directive - Application of Provisions. [Online] Available at: http://www.linklaters.com/Publications/20100218/Pages/01_AIFM_Directive_Appl ication_Provisions.aspx [Accessed 2 February 2014].

MFSA. (2013). A Guide to Setting Up an Alternative Investment Fund Manager.

Miller, R. G. (1991). Simultaneous Statistical Inference. New York: Springer-Verlag.

Muller C. \& Zanetti L. (2012). UCITS V: Lessons from the Crisis. Journal of Securities

Operations \& Custody, vol.5, Number 1, pp.73-79.

Njegomir, V \& Demko Rihter, J. (2013). Innovations of Insurance Companies and Investment Funds. Management Journal for Theory and Practice Management, 2013/68, pp.59-67.

Rajan, A. (2011). Investment Innovation: Raising the Bar. CREATE-Research, United Kingdom.

Rupeika-Apoga, R. and Nedovis Uraev, R. (2015). The Foreign Exchange Exposure of NonFinancial Companies in Eurozone: Myth or Reality? International Journal of Economics and Business Administration, 3(1), 54-66.

Saunders, M., Lewis, P. \& Thornhill. (2012). A. Research Methods for Business Students. Pearson, Harlow.

Savin, N.E. \& White, K.J. (1977). The Durbin-Watson Test for Serial Correlation with Extreme Sample Sizes or Many Regressors. Econometrica, Vol. 45, pp. 1989-1996.

Soper, D. (2014). A-Priori Sample Size Calculator for Multiple Regression. [Online] Available at: http://www.danielsoper.com/statcalc3/calc.aspx?id=1 [Accessed January 10, 2014].

Thalassinos, I.E., Pintea, M., Raţiu, I.P. (2015). The Recent Financial Crisis and Its Impact on the Performance Indicators of Selected Countries during the Crisis Period: A Reply. International Journal of Economics and Business Administration, 3(1), 3-20.

Woll, C. (2011). Beyond Ideological Battles: A Strategic Analysis of Hedge Fund Regulation in Europe. Les Cahiers européens de Sciences Po., N.02/2011, pp. 2-20.

World Economic Forum. (2013). The Global Competitiveness Report 2013-2014. [Online] Available at: http://www.weforum.org/reports/global-competitiveness-report-20132014 [Accessed 13 October 2013]. 